\title{
The Third Wave: Chinese Students' Values in Effective Mathematics Teaching in Two Secondary Schools ${ }^{1}$
}

\author{
ZHANG, Qiao-Ping \\ Department of Curriculum and Instruction, Chinese University of Hong Kong, \\ Shatin, N. T., Hong Kong SAR; qpzhang@cuhk.edu.hk
}

(Received June 9, 2014; Revised September 30, 2014; Accepted September 30, 2014)

\begin{abstract}
In the last few decades there has been much interest in how mathematics can be effectively taught and learnt. The Third Wave is a unique ongoing international collaborative mathematics education research project, which aims to explore the relevant values of effective school mathematics teaching from both the teacher and student perspectives. As part of this project, this study investigates the related findings from students on the Chinese mainland. Multiple data were collected through classroom observations, focus group interviews, and written, open-ended questions. Twenty-four students from junior and senior secondary schools were invited to write down their views on an effective lesson, a good mathematics teacher, and how to do well in mathematics learning. Results showed that among the eight values determined in the study, the values of involvement, explanation, and examples were embraced by students across all grades. Students preferred teacher-led mathematics teaching. Junior secondary students placed more value on teachers' personalities, whereas senior students placed more value on teachers' teaching manners.
\end{abstract}

Keywords: the Third Wave, effective mathematics lessons, effective mathematics teacher; values

MESC Classification: $\mathrm{C60}$

MSC2010 Classification: $97 \mathrm{C60}$

\section{INTRODUCTION AND BACKGROUND}

The ultimate goal of education research into curriculum reform and teacher development is to improve student learning. Classroom instruction plays a central role in student learning. How to teach effectively has been an important discussion in mathematics edu1 This project is supported by the Chinese University of Hong Kong for funding the research pro-
ject (Direct Grant Project Code: 2080084). 
cation for decades. About 25 years ago, the National Council of Teachers of Mathematics (NCTM) raised the topic of effective teaching in its year book Effective Mathematics Teaching:

'It becomes especially important that we develop a conceptually rich understanding of what effective mathematics teaching is and how to foster it' (Grouws \& Cooney, 1988, p. $1)$.

However, the construct of effective teaching is often ill-defined and subject to interpretation (Wilson, Cooney, \& Stinson, 2006). Most research studies do not precisely define what constitutes an effective mathematics lesson. They imply either that it is a wellagreed-upon construct or that it is so relative to any classroom context that it is meaningless to establish a single definition. Other research suggests that both these alternatives may be correct: within any community of practice, the concept of 'an effective lesson' is understood and agreed-upon by its members, yet the concept has a more flexible and culturally-inclusive meaning when used in different cultural contexts (Reynolds \& Muijs, 1999). Furthermore, research on effective teaching reveals that related terms may be used interchangeably, such as effective lessons, good teaching, good lessons, and competent teachers (Li, 2011; Clarke \& Xu, 2007; Pang, 2009; Shimizu, 2006).

Researchers have long tried to characterize the nature of effective teaching (Brophy \& Good, 1986). Early teaching effectiveness research hypothesized that certain teaching acts and conditions would affect student outcomes. At the time, process-product models were widely used. Various teaching approaches, such as direct teaching and reinforcement, served as process variables. Product variables referred to a variety of student outcomes such as student achievement or attitudes toward learning. Fraser et al. (1987) and Scheerens \& Bosker (1997) conducted meta-analyses and found a number of teaching process variables (e.g., reinforcement, feedback, cooperative learning,) positively related to student outcomes (e.g., achievement). Recently, researchers have concentrated on more global aspects of teaching. They have analysed teaching patterns or regimes instead of single teaching acts (Borko, 2004) and have focused on processes of learning in specific knowledge domains (De Corte, Verschaffel, Entwistle \& Merrienboer, 2003).

$\operatorname{NCTM}(2000$, p. 16) proposed that 'effective mathematics teaching requires understanding what students know and need to learn, and then challenging and supporting them to learn it well'. In a study of 'Effective Teachers of Numeracy in UK Primary Schools', researchers wanted to identify what teachers know and determine if that enables them to teach numeracy effectively (Askew, Brown, Rhodes, Johnson \& Wiliam, 1997). Results showed that high mean achievement gains were not necessarily related to specific teaching styles. Instead, effectiveness appeared to be associated with the teachers who had 'connectionist' orientations, focused on students' mathematical learning, provided a challenging curriculum, and held high expectations of initially low-attaining students. 
Many of these features reflect the value of meaningful and constructive classroom interactions between teacher and students, and perhaps also amongst students. In a review of research on effective mathematics teaching across the United Kingdom and the United States, Reynolds \& Muijs (1999) observed that the association of whole-class interactive teaching with student gains cannot be ignored. On the other hand, specific pedagogical practices might not be as significant. While 'we do not know as yet the extent of any 'context specificity' in the precise factors associated with gains in mathematics achievement ..., there are enough hints of the existence of this factor to make one wary of using undifferentiated methods in highly differentiated school contexts' (Reynolds \& Muijs, 1999, p. 285)

These findings have been confirmed in various international comparative studies such as the Trends in International Mathematics and Science Study (TIMSS), and Programme for International Student Assessment (PISA). They provide the educational research communities with a means of associating the performance rankings of countries with classroom teaching and learning practices and norms. They generally draw similar conclusions, that effective teaching is more about responding to and valuing the sociocultural aspect of the learning environment than it is about adopting particular teaching methods (Hollingsworth, Lokan, \& McCrae, 2003; OECD, 2004).

These different sociocultural contexts might be a major factor in explaining why effective teaching is ill-defined in research. Effective teaching can take many different forms, especially when teachers play a key role in determining what constitutes effective teaching in their own classrooms. Increasingly, research has investigated teachers' or students' views or beliefs on effective teaching from the affective aspects (Cai, 2007; Wilson, Conney, \& Stinson, 2005; Li, 2011; Perry, 2007; Wong, 2007Zan et al., 2006), which was the second wave in the mathematics education community ${ }^{2}$. Various researchers have indicated the importance of carrying comparative studies across countries and social contexts (Cai, Kaiser, Perry, \& Wong, 2009; Clark, Keitel, \& Shimizu, 2006). However, there is a lack of research on the views of students as to what constitutes effective teaching, particular on the Chinese mainland.

Cross-cultural comparative studies are also adopted by The Third Wave Project, which is a large cross-regional collaborative project. This project aims to discover how the effectiveness of mathematics teaching and learning could be optimised by harnessing the sociocultural factors involving values in schools. This study focuses on the socioaffective variables of values and valuing, rather than cognitive or affective factors. It looks at what a teacher and his/her students in the class co-value as the lesson unfolds, rather than what a teacher or student values separately. This approach judges effective

2 The first wave in the mathematics education community focused on cognitive research approaches. 
lessons to be the result of teacher-student and student-student interactions. Such a research approach is appropriate for a study with a regional comparative context. More research findings could be found in Seah \& Wong (2012); unfortunately, this project was not implemented on the Chinese mainland. It would be interesting to see how Chinese teachers and students value effective teaching, given that China has become more influential role in the international education community. The present study seeks to fill this knowledge gap.

The research aims to identify what constitutes effective mathematics teaching from the perspectives of students in Chinese mainland secondary schools. Specifically, this study looks at the following research questions:

(a) What constitutes an effective mathematics lesson?

(b) From a student's perspective, what constitutes an effective teacher?

In this study, we consider values as personal convictions that an individual regards as being important enough to be emphasized. This sociocultural perspective will be adopted to help us interpret what constitutes effectiveness in the lessons observed, and in turn to stimulate the conceptualisation of effective teaching. The terms 'good lesson' or 'effective lesson/teaching' are both used in the study.

\section{RESEARCH DESIGN}

\section{Research Participants and Methodology}

The Third Wave Project investigated to what degree the understanding valued by teachers and their students is underlying the effectiveness of mathematics teaching. In this study, we only report the students' responses. The city of Shenzhen, located in the south of the Chinese mainland, was chosen for this exploratory study. A total of 24 students from two secondary schools (12 junior secondary students from School A and 12 senior secondary students from school B) were invited to participate in the study. Students in Grades 7 and 8 were 13 and 14 years old, and students in Grades 10 and 11 were 15 and 16 years old respectively. The objectives of this study involve understanding, describing, discovering, hypothesis/theory generating, and all characteristics of qualitative research (Merriam, 1988; Miles \& Huberman, 1994; Neuman, 2003). The validity of the research findings will be enhanced through triangulation of data sources in two ways: through the use of multiple data sources (written documents, visual documents, lesson observations, interviews, and field research notes), and through the inclusion of a cross-checking mechanism within each data source. 


\section{Data Collection and Analysis}

The data collection process includes the following sections: lesson observation, an open-ended questionnaire, and student focus group interviews. Below is a brief description of each section.

\section{Lesson Observation}

Three mathematics lessons facilitated by the teacher were observed, and provided the basis for the student interview sessions. During the observed lessons, the student participants were encouraged to 'tell' observers about the moments of effective learning. In some other teams of the Third Wave project, digital still cameras were used to take snapshots of the effective moments (Lim, 2012). In this study, both observers and a video camera recorded the student's behaviour. Additionally, researchers gave each student a bottle of water before the lesson. The students could raise the bottle when they felt that they were learning mathematics particularly well in the class.

\section{Open-Ended Questionnaire}

Each student participant was asked to fill in an open-ended questionnaire before an interview. The questionnaire included the following three questions:

- A good mathematics lesson should be:

- A good mathematics teacher should be:

- To learn mathematics well, one should

These questions investigated student views of effective mathematics teaching and learning, and also provided a basis for discussion in the student focus group interviews.

\section{Student Focus Group Interviews}

The student focus group interviews were conducted after the lessons and questionnaire were completed. Student participants were expected to talk about the effective moments recorded by researchers in the classroom, and to validate what they found important at the respective moments of effective learning. Each student was encouraged to talk about the extent to which identified values were unique and personal to them, and the extent to which they emphasised those values in their mathematics learning experiences. The focus group sessions were audio-taped to facilitate researcher recall during the analysis process.

All the data were analysed through a multiple-pass approach, utilizing the three-staged open, axial, and selective coding that typifies the grounded theory research approach (Strauss \& Corbin, 1990). This approach has been found to be relevant for use in the absence of a theoretical framework related to values research (Seah \& Peng, 2012). In this study, we focus on the analysis of the responses to the open-ended questionnaire. Other 
sections are still being analysed.

\section{RESULTS AND DISCUSSION}

\section{What constitutes a good mathematics lesson?}

The responses of both junior and senior students to what constitutes a good/effective lesson were reviewed. These responses were summarised in eight values as shown in Table 1 , together with corresponding descriptors. These values are fun, involvement, creativity, board work, multiple methods, explanation, focus and examples. Some of these values were also found in other education systems. For example, the fun of learning mathematics or an enjoyable atmosphere were also valued by Taiwanese high school students (Chin \& Lin, 2000), German high-ability secondary students (Keitel 2003), Hong Kong junior secondary students (Law, Wong \& Lee, 2012), and Swedish and Australian primary students (Seah \& Peng, 2012). While the meaning of fun has subtle differences in different studies - for example, in Seah \& Peng's (2012) study - the value of fun reported by students implied a fun atmosphere in mathematics or the jokes and/or games during lessons. Hong Kong students valued playing games or doing quizzes in a lively and enjoyable environment (Law, Wong \& Lee, 2012). In Chin \& Lin's (2000) study, fun was related to interesting mathematics problems that could raise student curiosity. In this study, the value of fun was mentioned by 12 students (50\%), particularly by junior secondary students, as an enjoyable classroom atmosphere. The values of involvement, explanation, and examples were embraced by students across all grades. There were 14, 12 and 7 students mentioned these values respectively. It was found that students, particularly junior secondary students, expected more interactions in the classroom. Although we could not conclude that more interactions would lead to an enjoyable or interesting classroom atmosphere, these two values (fun and involvement) did have a close relationship in the study. Teachers' clear and detailed explanations were also important, which included giving summaries and explaining the relationships between mathematical concepts.

From the results, we can see that many students (58\%) valued high involvement in the classroom. In addition, a teacher-led environment was valued by the majority of students. Board work and focus were only valued by senior secondary students. Board work was also valued by Malaysian primary students (Lim, 2012) in an earlier study. The Chinese Mainland student participants viewed board work as a mechanism for receiving information from teachers, while the Malaysian primary students in Lim's study viewed it as a mechanism for exchanging information. Three Grade 11 students emphasized the importance of focus in an effective mathematics lesson, a finding which does not appear in other studies. 
Table 1. Interview questions and how they correspond to PCK categories

\begin{tabular}{|c|c|c|c|c|c|}
\hline \multirow[b]{2}{*}{ Value } & \multirow[b]{2}{*}{ Descriptors } & \multicolumn{2}{|c|}{ Junior } & \multicolumn{2}{|c|}{ Senior } \\
\hline & & $\begin{array}{l}\text { Grade } 7 \\
(n=6)\end{array}$ & $\begin{array}{c}\text { Grade } 8 \\
(\mathrm{n}=6)\end{array}$ & $\begin{array}{l}\text { Grade } 10 \\
\quad(n=6)\end{array}$ & $\begin{array}{l}\text { Grade } 11 \\
\quad(n=6)\end{array}$ \\
\hline Fun & $\begin{array}{l}\text { fun/enjoyable atmosphere in } \\
\text { mathematics lesson }\end{array}$ & $\sqrt{\sqrt{ } \sqrt{ } \sqrt{ }}$ & $\sqrt{\sqrt{ }}$ & $\sqrt{\sqrt{ } \sqrt{ }}$ & \\
\hline $\begin{array}{l}\text { Involve- } \\
\text { ment }\end{array}$ & $\begin{array}{l}\text { more teacher-student or stu- } \\
\text { dent-student interaction in the } \\
\text { classroom, motivate students, } \\
\text { active participation }\end{array}$ & $\sqrt{ } \sqrt{ } \sqrt{ } \sqrt{ } \sqrt{ }$ & $\sqrt{ } \sqrt{ }$ & $\sqrt{ } \sqrt{ }$ & $\sqrt{ } \sqrt{ }$ \\
\hline Creativity & $\begin{array}{l}\text { inspire or develop students' } \\
\text { thinking, creativity }\end{array}$ & $\sqrt{ } \sqrt{ }$ & $\sqrt{ } \sqrt{ } \sqrt{ }$ & & $\sqrt{ } \sqrt{ }$ \\
\hline $\begin{array}{l}\text { Board } \\
\text { writing }\end{array}$ & $\begin{array}{l}\text { clear and detailed writing on } \\
\text { the blackboard }\end{array}$ & & & $\sqrt{ }$ & \\
\hline $\begin{array}{l}\text { Multiple } \\
\text { methods }\end{array}$ & $\begin{array}{l}\text { using new, multiple methods to } \\
\text { solve problems }\end{array}$ & $\sqrt{ } \sqrt{ }$ & $\sqrt{ } \sqrt{ }$ & $\sqrt{ } \sqrt{ }$ & \\
\hline $\begin{array}{l}\text { Explana- } \\
\text { tion/ } \\
\text { Instruction }\end{array}$ & $\begin{array}{l}\text { summaries by teacher, expand } \\
\text { relationships between concepts } \\
\text { by teacher, gradually progress, } \\
\text { detailed explanation }\end{array}$ & $\sqrt{ } \sqrt{ } \sqrt{ }$ & $\sqrt{ }$ & $\sqrt{ } \sqrt{ }$ & $\sqrt{ } \sqrt{ } \sqrt{ }$ \\
\hline Focus & $\begin{array}{l}\text { important knowledge points, } \\
\text { different knowledge points }\end{array}$ & & & & $\sqrt{ } \sqrt{ }$ \\
\hline Examples & $\begin{array}{l}\text { provide classical/typical or } \\
\text { high-order thinking problems }\end{array}$ & $\sqrt{ }$ & $\sqrt{ }$ & $\sqrt{ }$ & $\sqrt{ } \sqrt{ } \sqrt{ }$ \\
\hline
\end{tabular}

Note: $\sqrt{ }$ means this value was mentioned by a student.

What constitutes a good mathematics teacher?

We also investigated student views on what constitutes an effective mathematics teacher. As shown in Table 2, a good mathematics teacher is expected to have humour, clear expressions, and lively and skilful teaching He or she should also encourage and motivate students, according to the answers from across four grades. In particular, $10 \mathrm{stu}-$ dents (42\%) highlighted the importance of teachers' encouragement. Only junior secondary students proposed that a good mathematics teacher should be genial and patient. Here, Patience means the teacher could explain problems to students patiently. Patience was also valued in Mexican high school students in another study (Martínez-Sierra, 2012). In that research, $16 \%$ of students reported that a good mathematics teacher would be someone who is accessible and treats the class in a friendly and tolerant way. That description was similar to the definition of Patience used in this study. As shown in Table 2, junior secondary students placed more value on teachers' personalities (e.g., having passion, affability, humour, and patience), whereas senior students placed more value on teachers' teaching manner (e.g., lively, having focus, motivating students). 
Table 2. Characteristics of a Good Mathematics Teacher

\begin{tabular}{|c|c|c|c|c|}
\hline \multirow[b]{2}{*}{$\begin{array}{c}\text { Characteristics of a good mathematics } \\
\text { teacher }\end{array}$} & \multicolumn{2}{|c|}{ Junior } & \multicolumn{2}{|c|}{ Senior } \\
\hline & $\begin{array}{l}\text { Grade } 7 \\
(\mathrm{n}=6)\end{array}$ & $\begin{array}{c}\text { Grade } 8 \\
(\mathrm{n}=6)\end{array}$ & $\begin{array}{c}\text { Grade } 10 \\
(\mathrm{n}=6)\end{array}$ & $\begin{array}{c}\text { Grade } 11 \\
(\mathrm{n}=6)\end{array}$ \\
\hline Passion & $\sqrt{\sqrt{ }}$ & & & $\sqrt{ }$ \\
\hline Genial/not serious & $\sqrt{ } \sqrt{ } \sqrt{ }$ & $\sqrt{ } \sqrt{ } \sqrt{ }$ & & \\
\hline Serious & & $\sqrt{ }$ & $\sqrt{ }$ & \\
\hline Humorous & $\sqrt{ } \sqrt{ }$ & $\sqrt{ } \sqrt{ }$ & $\sqrt{ }$ & $\sqrt{ }$ \\
\hline Patient & $\sqrt{ } \sqrt{ } \sqrt{ }$ & & & \\
\hline Language (clear, cadenced) & $\sqrt{ }$ & $\sqrt{ } \sqrt{ }$ & $\sqrt{ } \sqrt{ }$ & $\sqrt{ }$ \\
\hline Interaction & $\sqrt{ } \sqrt{ }$ & $\sqrt{ }$ & $\sqrt{ }$ & $\sqrt{ }$ \\
\hline Teaching is easy to understand/accessible & $\sqrt{ } \sqrt{ }$ & & $\sqrt{ }$ & $\sqrt{ }$ \\
\hline Lively/skilful teaching & $\sqrt{ }$ & $\sqrt{ } \sqrt{ }$ & $\sqrt{ }$ & $\sqrt{ } \sqrt{ }$ \\
\hline Board work & & & $\sqrt{ }$ & \\
\hline Reasonable homework & $\sqrt{ }$ & & & $\sqrt{ }$ \\
\hline Focus & & $\sqrt{ } \sqrt{ }$ & $\sqrt{ } \sqrt{ }$ & $\sqrt{ } \sqrt{ }$ \\
\hline Examples & & $\sqrt{ }$ & $\sqrt{ } \sqrt{ }$ & \\
\hline Encourage/motivate students & $\sqrt{ } \sqrt{ }$ & $\sqrt{ } \sqrt{ }$ & $\sqrt{ }$ & $\sqrt{ } \sqrt{ } \sqrt{ } \sqrt{ }$ \\
\hline Multiple methods & $\sqrt{ }$ & $\sqrt{ }$ & $\sqrt{ } \sqrt{ } \sqrt{ }$ & \\
\hline Creativity & $\sqrt{ } \sqrt{ } \sqrt{ }$ & $\sqrt{ }$ & & $\sqrt{ } \sqrt{ }$ \\
\hline
\end{tabular}

What is important in mathematics learning?

When we moved from the subject of teacher/lesson to student learning, we found some different aspects that students valued in their mathematics learning, and some common factors that could be related to their views on effective teaching (see Table 3). To do well in mathematics, students across all grades proposed the values of practice, communication, interest (in math), and mathematical thinking. In particular, more than half of the total students surveyed (54\%) thought that practice was very important in their learning. Lots of practice and exercise leading to successful mathematics learning was also covalued by Malaysian primary students and teachers (Lim, 2012). Following the value of practice was mathematical thinking, which was mentioned by $50 \%$ of the students surveyed. At the same time, Instruction, especially listening to teacher carefully was also important (42\%), which was similar to the result shown in Table 1. We can see that a teacher-led mathematics teaching was preferred by most students. Involvement, examples, and multiple methods were also mentioned. There was some difference between the value of involvement as shown in Table $1(\mathrm{n}=14)$ and Table $3(\mathrm{n}=2)$. It seemed that involvement was more important for effective teaching than for student learning. Four senior secondary students mentioned that learning mathematics well would require a positive attitude (such as unpresumptuous, strict, and serious). 
Table 3. Values Associated with Mathematics Learning

\begin{tabular}{|c|c|c|c|c|}
\hline \multirow[b]{2}{*}{ Values } & \multicolumn{2}{|c|}{ Junior } & \multicolumn{2}{|c|}{ Senior } \\
\hline & $\begin{array}{c}\text { Grade } 7 \\
(n=6)\end{array}$ & $\begin{array}{c}\text { Grade } 8 \\
(n=6)\end{array}$ & $\begin{array}{c}\text { Grade } 10 \\
(\mathrm{n}=6)\end{array}$ & $\begin{array}{c}\text { Grade } 11 \\
(n=6)\end{array}$ \\
\hline Practice & $\sqrt{\sqrt{ } \sqrt{ } \sqrt{ }}$ & $\sqrt{ } \sqrt{ }$ & $\sqrt{ } \sqrt{ }$ & $\sqrt{ } \sqrt{ }$ \\
\hline Communication & $\sqrt{ } \sqrt{ }$ & $\sqrt{ }$ & $\sqrt{ } \sqrt{ }$ & $\sqrt{ }$ \\
\hline Instruction & $\sqrt{ } \sqrt{ } \sqrt{ }$ & $\sqrt{ } \sqrt{ }$ & $\sqrt{ }$ & $\sqrt{ } \sqrt{ } \sqrt{ }$ \\
\hline Involvement & $\sqrt{ }$ & & & $\sqrt{ }$ \\
\hline Examples & & $\sqrt{ } \sqrt{ } \sqrt{ }$ & $\sqrt{ }$ & $\sqrt{ }$ \\
\hline Multiple methods & & $\sqrt{ }$ & $\sqrt{ } \sqrt{ }$ & $\sqrt{ } \sqrt{ }$ \\
\hline Summarize/reflect & & $\sqrt{ } \sqrt{ } \sqrt{ }$ & $\sqrt{ } \sqrt{ }$ & $\sqrt{ }$ \\
\hline Memorising & & & $\sqrt{ }$ & \\
\hline Knowledge structure & & & $\sqrt{ }$ & $\sqrt{ } \sqrt{ }$ \\
\hline Homework & $\sqrt{ }$ & & & $\sqrt{ }$ \\
\hline Interest (in math) & $\sqrt{ }$ & $\sqrt{ }$ & $\sqrt{ }$ & $\sqrt{ }$ \\
\hline Attitude & & & $\sqrt{ }$ & $\sqrt{ } \sqrt{ }$ \\
\hline Mathematical Thinking & $\sqrt{ }$ & $\sqrt{ } \sqrt{ } \sqrt{ }$ & $\sqrt{ }$ & $\sqrt{ } \sqrt{ } \sqrt{ } \sqrt{ } \sqrt{ }$ \\
\hline
\end{tabular}

\section{CONCLUSION AND IMPLICATIONS}

This study aimed to identify specific understandings of what constitutes effective mathematics teaching, from the perspective of students in Chinese mainland secondary schools. Eight values in effective mathematics teaching were determined using an openended questionnaire: fun, involvement, creativity, board work, multiple methods, explanation, focus and examples.

Although some of the values have been found in studies of other education systems, there are some unique values in the Chinese mainland context. For example, in Malaysia, students valued board writing as a platform to learn from other students, while on the Chinese mainland, students wanted to learn more from teachers' detailed and clear writing on the blackboard. In particular, Chinese mainland students emphasized the focus of effective mathematics teaching, which was not mentioned in previous studies. Specifically, in an effective lesson there should be important knowledge points and difficult knowledge points (these were also found to be requirements of effective mathematics teaching). While many students (58\%) valued involvement in the classroom, teachers' clear and detailed explanations were also important, which included giving summaries and establishing relationships between mathematical concepts. In addition, 50\% of students valued an enjoyable classroom environment (fun). However, from the written questionnaire we could not determine the real meaning of an enjoyable environment. Indeed, there are subtle differences between studies about the value of fun. Could it mean playing games or doing quizzes, or interactions between teacher and students? Further investigation (such as student group interviews) is needed to clarify the meaning of each value. 
From the study, we can also determine some differences between junior secondary and senior secondary students. For example, junior secondary students (37\%) placed more emphasis on involvement than senior secondary students (21\%) (Table 1). Junior secondary students placed more value on teachers' personalities (having passion, affability, humour, and patience), while senior students placed more value on teachers' teaching manner (e.g., lively, having focus, motivating students) (Table 2). Both junior and senior secondary students valued practice and teachers' explanations in mathematics learning (Table 3 and Table 1).

From the analysis, we can see that teachers play an important role in the classroom. The Chinese mainland students depended on their teacher in the classroom, and a teachercentred environment for mathematics teaching was preferred. This can be seen from students' views on effective mathematics learning. In Table 3, $42 \%$ of students thought one needed to listen to the teacher carefully in order to do well in mathematics.

The present study demonstrates the desires and expectations of a sample of secondary students on the Chinese mainland in relation to the teaching of mathematics. Given the small number of participants, one must be cautious when generalising the findings in this study. In particular, the analysis was only based on part of the qualitative data. Once these data are combined with classroom observations and focus group interviews, we may have a more holistic picture of students' values towards effective teaching. The findings showed the students' most appreciated and important values, and these values are subject to student preferences or choices. Bishop (2012) proposed that understanding student values in relation to mathematics teaching allows us to draw closer to levels of mathematical well-being. Teachers can have a better understanding of what their students find important in mathematics learning, and thus they can design more effective pedagogies for facilitating classroom learning.

\section{ACKNOWLEDGMENTS}

The author would like to thank Dr. SEAH Wee Tiong, the team leader of The Third Wave Project, and all the participants in this study. Many thanks are also given to the reviewers' constructive comments and Miss Irene who has provided helpful comments and suggestions on an earlier draft of this paper. Finally, the author gratefully acknowledges the support by The Chinese University of Hong Kong for funding the research project (Direct Grant Project Code: 2080084). 


\section{REFERENCES}

Askew, M.; Brown, M.; Rhodes, V.; Johnson, D. \& William, D. (1997). Effective teachers of numeracy. Report of a study carried out for the Teacher Training Agency 1995-96. Final report. London, UK: School of Education, King's College. ME 2000b.00890

Bishop, A. J. (2012). From culture to well-being: a partial story of values in mathematics education. ZDM, Int. J. Math. Educ. 44(1), 3-8. ME 2012e.00280

Borko, H. (2004). Professional development and teacher learning: Mapping the terrain. Educational Researcher 33(8), 3-15.

Brophy, J., \& Good, T. (1986). Teacher behavior and student achievement. In: M. Wittrock (Ed.), Handbook of research on teaching, 3rd ed. (pp. 328-375). New York: Macmillan.

Cai, J. (2007). What is effective mathematics teaching? A study of teachers from Australia, mainland China, Hong Kong SAR, and the United States. ZDM, Int. J. Math. Educ. 39(4), 265-270. ME 2007e.00143

Cai, J.; Kaiser, G.; Perry, B. \& Wong, N. Y. (eds.) (2009). Effective mathematics teaching from teachers' perspectives: National and cross-national studies Rotterdam, Netherlands: Sense Publishers. ME 2010c.00041

Chin, C. \& Lin, F. L. (2000). Values and values statement emerged in students' preferences on test items: A case study from mathematical induction. Paper presented at the History and Pedagogy of Mathematics 2000 Conference, Taipei, Taiwan.

Clarke, D.; Keitel, C. \& Shimizu, Y. (2006). Mathematics classrooms in twelve countries. The insider's perspective. Rotterdam, Netherlands: Sense Publishers. ME 2013e.00108

Clarke, D. J. \& Xu, L. H. (2007). Examining Asian mathematics classrooms through the lens of the distribution of responsibility for knowledge generation. In: C. S. Lim, S. Fatimah, S. Hajar, M. Y. Hashimah, W. L. Gan \& T. Y. Hwa (Eds.), Proceedings of the Fourth East Asia Regional Conference on Mathematics Education (pp. 518-524). Penang, Malaysia: Universiti Sains Malaysia.

De Corte, E.; Verschaffel, L.; Entwistle, N. \& van Merrienboer, J. (Eds.). (2003). Powerful learning environments: Unravelling basic components and dimensions. Amsterdam: Pergamon.

Fraser, B. J.; Walberg, H. J.; Welch, W. W. \& Hattie, J. A. (1987). Syntheses of educational productivity research. International Journal of Educational Research 11(2), 145-252,

Grouws, D. A. Cooney, T. J. \& Jones, D. (Eds.) (1988). Perspectives on research on effective mathematics teaching. Reston, VA: National Council of Teachers of Mathematics / Hillsdale, NJ: Erlbaum. ME 1989k.00600

Hollingsworth, H.; Lokan, J. \& McCrae, B. (2003). Teaching mathematics in Australia: Results from the TIMSS 1999 Video Study. Camberwell, VIC: Australian Council for Educational Research. 
Keitel, C. (2003). Values in mathematics classroom practice: The students' perspective. Paper presented at the Conference of the Learners' Perspective Study international research team.

Law, H. Y.; Wong, N. Y. \& Lee, N. Y. L. (2012). A study into espoused values in Hong Kong mathematics classrooms. ZDM, Int. J. Math. Educ. 44(1), 45-57. ME 2012e.00294

Li, Y. (2011). Elementary teachers' thinking about a good mathematics lesson. Int. J. Sci. Math. Educ. 9(4), 949-973.

Lim, C. S. (2012). Riding the third wave: Negotiating teacher and students' value preferences relating to effective mathematics lesson. Paper presented at the 12th International Congress on Mathematical Education. July 8 - 15, 2012, COEX, Seoul, Korea.

Martínez-Sierra, G. (2012). Good mathematics teaching from the perspective of Mexican high school students. Paper presented at the MAVI-18 Conference. September 12-15 Helsinki, Finland.

Merriam, S. B. (1988). Case study research in education: A qualitative approach. San Francisco, California, USA: Jossey-Bass Publishers.

Miles, M. B., \& Huberman, A. M. (1994). Qualitative data analysis: An expanded sourcebook (2nd edition). Thousand Oaks, California, USA: Sage Publications.

National Council of Teachers of Mathematics [NCTM] (2000). Principles and standards for school mathematics. Reston, VA: NCTM. ME 1999f.03937 for discussion draft (1998)

Neuman, W. L. (2003). Social research methods: Qualitative and quantitative approaches (5th edition). Boston, Massachusetts, USA: Pearson Education.

Organization for Economic Cooperation and Development [OECD] (2004). Learning for tomorrow's world: First results from PISA 2003. Paris, France: OECD Publishing.

Pang, J. S. (2009). Good mathematics instruction in South Korea. ZDM, Int. J. Math. Educ. 41(3), 349-362. ME 2009f.00296

Perry, B. (2007). Australian teachers' views of effective mathematics teaching and learning. ZDM, Int. J. Math. Educ. 39(4), 271-286. ME 2009e.00144

Reynolds, D. \& Muijs, D. (1999). The effective teaching of mathematics: A review of research. School Leadership and Management 19(3), 273-288.

Scheerens, J. \& Bosker, R. J. (1997). The Foundations of Educational Effectiveness. Oxford: Elsevier Science Ltd.

Seah, W. T. \& Peng, A. (2012). What students outside Asia value in effective mathematics lessons: a scoping study. ZDM, Int. J. Math. Educ. 44(1), 71-82. ME 2012e.00379

Seah, W. T. \& Wong, N. Y. (2012). What students value in effective mathematics learning: a 'Third Wave Project' research study. ZDM, Int. J. Math. Educ. 44(1), 33-43. ME 2012e.00378

Shimizu, Y. (2006). Discrepancies in perceptions of mathematics lessons between the teacher and the students in a Japanese classroom. In: D. Clarke, C. Keitel \& Y. Shimizu (Eds.), Mathematics classrooms in twelve countries: The insider's perspective (pp. 183-194). Rotterdam: Sense Publishers. ME 2013e.00108 
Strauss, A. \& Corbin, J. (1990). Basics of qualitative research: Grounded theory procedures and techniques. Newbury Park, California, USA: Sage Publications.

Wilson, P.; Cooney, T. \& Stinson, D. (2005). What constitutes good mathematics teaching and how it develops: Nine high school teachers' perspectives. J. Math. Teach. Educ. 8(2), 83-111. ME 2005f. 02631

Wong, N. Y. (2007). Hong Kong teachers' views of effective mathematics teaching and learning. ZDM, Int. J. Math. Educ. 39(4), 301-314. ME 2009e.00146

Zan, R.; Brown, L.; Evens, J. \& Hannula, M. S. (2006). Affect in mathematics education: An introduction. Educ. Stud. Math. 63(2), 113-121. ME 2007f.00052 